\title{
MOBILITY AND BIOAVAILABILITY OF HEAVY METALS AND METALLOIDS IN SOIL ENVIRONMENTS
}

\author{
A. Violante ${ }^{1 *}$, V. Cozzolino ${ }^{1}$, L. Perelomov ${ }^{2}$, A.G. Caporale ${ }^{1}$, and M. Pigna ${ }^{1}$. \\ ${ }^{1}$ Dipartimento di Scienze del Suolo, della Pianta e dell'Ambiente, Università di Napoli Federico \\ II, Portici (Napoli), Italy. ${ }^{2}$ Tula State University, Lenin Avenue, 92, Tula, 300600, Russia. \\ *Corresponding author: violante@unina.it
}

\begin{abstract}
In soil environments, sorption/desorption reactions as well as chemical complexation with inorganic and organic ligands and redox reactions, both biotic and abiotic, are of great importance in controlling their bioavailability, leaching and toxicity. These reactions are affected by many factors such as $\mathrm{pH}$, nature of the sorbents, presence and concentration of organic and inorganic ligands, including humic and fulvic acid, root exudates, microbial metabolites and nutrients. In this review, we highlight the impact of physical, chemical, and biological interfacial interactions on bioavailability and mobility of metals and metalloids in soil. Special attention is devoted to: i) the sorption/desorption processes of metals and metalloids on/from soil components and soils; ii) their precipitation and reduction-oxidation reactions in solution and onto surfaces of soil components; iii) their chemical speciation, fractionation and bioavailability.
\end{abstract}

Keywords: bioavailability, heavy metals, metalloid, adsorption, desorption, chemical speciation

\section{INTRODUCTION}

Characterizing the factors affecting bioavailability, leaching and toxicity of metals and metalloids in soil is of paramount importance. Metals and metalloids are significant natural components of all soils where their presence in the mineral fraction comprises a store of potentially-mobile metal species as important components of clays, minerals and iron and manganese oxides that, in turn, have a dramatic influence on soil geochemistry (Gadd, 2008). Metals are also present in the organic fraction, frequently as bound forms, with some metal recycling occurring as a result of organic matter decomposition. The aqueous phase provides a mobile medium for chemical reactions, metal transfer and circulation through the soil, to organisms, and also to the aquatic environment.

Heavy metals and metalloids can be involved in a series of complex chemical and biological interactions. The most important factors which affect their mobility are $\mathrm{pH}$, sorbent nature, presence and concentration of organic and inorganic ligands, including humic and fulvic acids, root exudates and nutrients. Furthermore, redox reactions, both biotic and abiotic, are of great importance in controlling the oxidation state and thus, the mobility and the toxicity of many elements, such as $\mathrm{Cr}$, Se, $\mathrm{Co}, \mathrm{Pb}, \mathrm{As}, \mathrm{Ni}$ and $\mathrm{Cu}$. Redox reactions can mobilize or immobilize metals, depending on the 
particular metal species and microenvironments.

\section{REDOX REACTIONS AND METAL TRANSFORMATIONS}

The reductive transformation of some heavy metals may proceed chemically, for example $\mathrm{Cu}$ (II) reduction to $\mathrm{Cu}(\mathrm{I})$ by $\mathrm{Fe}^{2+}$ or $\mathrm{H}_{2} \mathrm{~S}$ and reduction of $\mathrm{Cu}(\mathrm{II}), \mathrm{Ag}(\mathrm{II})$, and $\mathrm{Hg}(\mathrm{II})$ to elemental forms by $\mathrm{Fe}(\mathrm{II})$ bearing green-rust (Borch et al., 2010; and references therein). Microorganisms may directly reduce many highly toxic metals (e.g., $\mathrm{Cr}, \mathrm{Hg}, \mathrm{U}$ ) via detoxification pathways. Microbial reduction of certain metals to a lower redox state may result in reduced mobility and toxicity. Such processes may accompany other metal precipitation mechanisms. Aerobic and anaerobic reduction of $\mathrm{Cr}$ (VI) to $\mathrm{Cr}$ (III) is widespread in microorganisms (Gadd, 2008).

Sulfate reduction in contaminated soils may mobilize $\mathrm{Cu}, \mathrm{Pb}$, and $\mathrm{Cd}$ through the formation of $\mathrm{Cu}$-rich sulphide colloids. Sulphate-reducing bacteria (SRB) oxidise organic compounds or hydrogen coupled with the reduction of sulphate, producing sulphide. The solubility product of most heavy metal sulphides is very low, so that even a moderate output of sulphide can remove metals from solution. As reviewed by Borch et al. (2010) biogeochemical oxidation processes are driven by $\mathrm{O}_{2}$ entering anoxic systems. Certain oxidation processes such as $\mathrm{Fe}$ (II) oxidation by $\mathrm{O}_{2}$ at neutral to alkaline $\mathrm{pH}$ proceed rapidly abiotically, but many slower processes are facilitated by chemotrophic microorganisms.

Precipitation of $\mathrm{Fe}-, \mathrm{Mn}-$, and Al(hydr)oxides may efficiently capture dissolved trace metals (Violante et al., 2008). If the precipitates formed during oxidative precipitation are nanoparticulate and colloidal, they may greatly enhance the mobility of associated trace metals in aquatic and subsurface environments.

Biogeochemical redox processes strongly influence also metalloids mobility such as arsenic (As) and antimony (Sb). Whereas environmental As chemistry has received great attention during the last two decades due to the worldwide health impacts of As contaminated drinking water and soils, $\mathrm{Sb}$ may locally represent an important contaminant, for example in the vicinity of copper and lead ore smelters. Oxidation of $\mathrm{Sb}(0)$ to $\mathrm{Sb}(\mathrm{III})$ or $\mathrm{Sb}(\mathrm{V})$, as well as sorption to $\mathrm{Fe}$ (hydr)oxides, controls $\mathrm{Sb}$ toxicity and mobility at these sites.

The As mobility, bioavailability, toxicity, and environmental fate are controlled by biogeochemical transformations that either form or destroy As-bearing carrier phases, or modify the redox state and chemical As speciation (see Figure 2 and Table 1 in Borch et al., 2010).

Arsenic in natural waters and soils is intimately related to the presence of iron (hydr)oxides being arsenate and arsenite strongly sorbed onto the surfaces of Feoxides, forming inner-sphere complexes. The simultaneous presence of high dissolved As and $\mathrm{Fe}(\mathrm{II})$ concentrations in anoxic groundwater has led to the conclusion that reductive dissolution of As rich $\mathrm{Fe}(\mathrm{III})$ (hydr)oxides mobilizes geogenic As (see Figure 2 in Borch et al., 2010). More recently, it has been demonstrated that microbial sulphide formation in As-ferrihydrite systems leads to transformation and dissolution of the As-bearing ferrihydrite. Direct reduction of $\mathrm{Fe}$ (III) by microorganisms can lead to As sequestration by sorption of As onto secondary $\mathrm{Fe}$ minerals (see Figure 2 in Borch et al., 2010).

Clays and oxides often demonstrate the ability to catalyze electron transfer 
reactions. Abiotic redox processes occur on the surfaces of humic substances $\mathrm{Fe}(\mathrm{III})$ and Mn-oxides as depicted in Figure 1. Iron and manganese oxides and layer silicates with structural Fe(III) are the most active in this regard. Redox reactions also control the transformation and Fe- reactivity and Mn-oxides in soils, which are the major sinks for heavy metals and metalloids. The Mn oxides efficiency as "electron pump" for a wide range of redox reactions is unique among common soil minerals.

Redox reactive metals often do have different degrees of toxicity depending on the specific metal oxidation state. For example, chromate is toxic to plants, animals and humans and is a suspected carcinogen, whereas $\mathrm{Cr}$ (III) is not toxic to plants and is necessary in animal nutrition, so that reactions that reduce $\mathrm{Cr}(\mathrm{VI})$ to $\mathrm{Cr}(\mathrm{III})$ are of great importance. Furthermore, $\mathrm{Cr}(\mathrm{VI})$ is mobile in soils and readily available. Organic material, sulfides, and ferrous species appear to be the dominant reductants. Very stable $\mathrm{Cr}$ (III)-organic complexes form when $\mathrm{Cr}(\mathrm{VI})$ is reduced by soil organic matter (Fendorf, 1995).

\section{SORPTION / DESORPTION PROCESSES OF HEAVY METALS AND METALLOIDS}

The soil components responsible for trace element sorption include, soil humic substances, phyllosilicates, carbonates and variable charge minerals (constituents such as $\mathrm{Fe}, \mathrm{Al}, \mathrm{Mn}$ and Ti oxides, shortrange ordered aluminosilicates as well as phyllosilicates coated by $\mathrm{OH}-\mathrm{Al}$ or $\mathrm{OH}-$ Fe species whose charge varies with the $\mathrm{pH}$ of the soil solution).

Evidence on the sorption of heavy metals on microorganisms has been reported. Soil components differ greatly in their sorption capacities, their cation and anion exchange capacities, and the binding energies of their sorption sites.

\section{Sorption of cationic metal species}

Heavy metals show typical ion exchange behavior on layer silicate clays with permanent charge, demonstrating essentially the same affinity for exchange sites on the clays as do alkaline earth metals having the same charge and similar ionic radius. Surface bonding is electrostatic, dependent only on the charge and hydration properties of the cation. Trace elements in cationic form are probably not dominantly sorbed on phyllosilicates because they are always vastly outnumbered by other cations with which they compete (e.g. Ca). They may be strongly sorbed only on the edges of the phyllosilicates. However, clay minerals have also an important role as carriers of associated oxides and humic substances forming organo-mineral complexes, which present peculiar sorption capacities different from those of each single soil constituent.

There are two general surface complexes and are described by the configuration geometry of the adsorbate at the adsorbent surface. These include inner- and outer-sphere surface complexes and are defined by the presence, or absence, of the hydration sphere of the adsorbate molecule upon interaction. When at least one water molecule of the hydration sphere is retained upon sorption, the surface complex is referred to as outer-sphere. When the ion is bound directly to the adsorbent without the presence of the hydration sphere, an inner-sphere complex is formed (Sposito, 1984; Sparks, 2003; Borda and Sparks, 2008).

Humic matter and metal oxides are much more effective sorbents of heavy metals in cationic form than even the most efficient sorbent among 


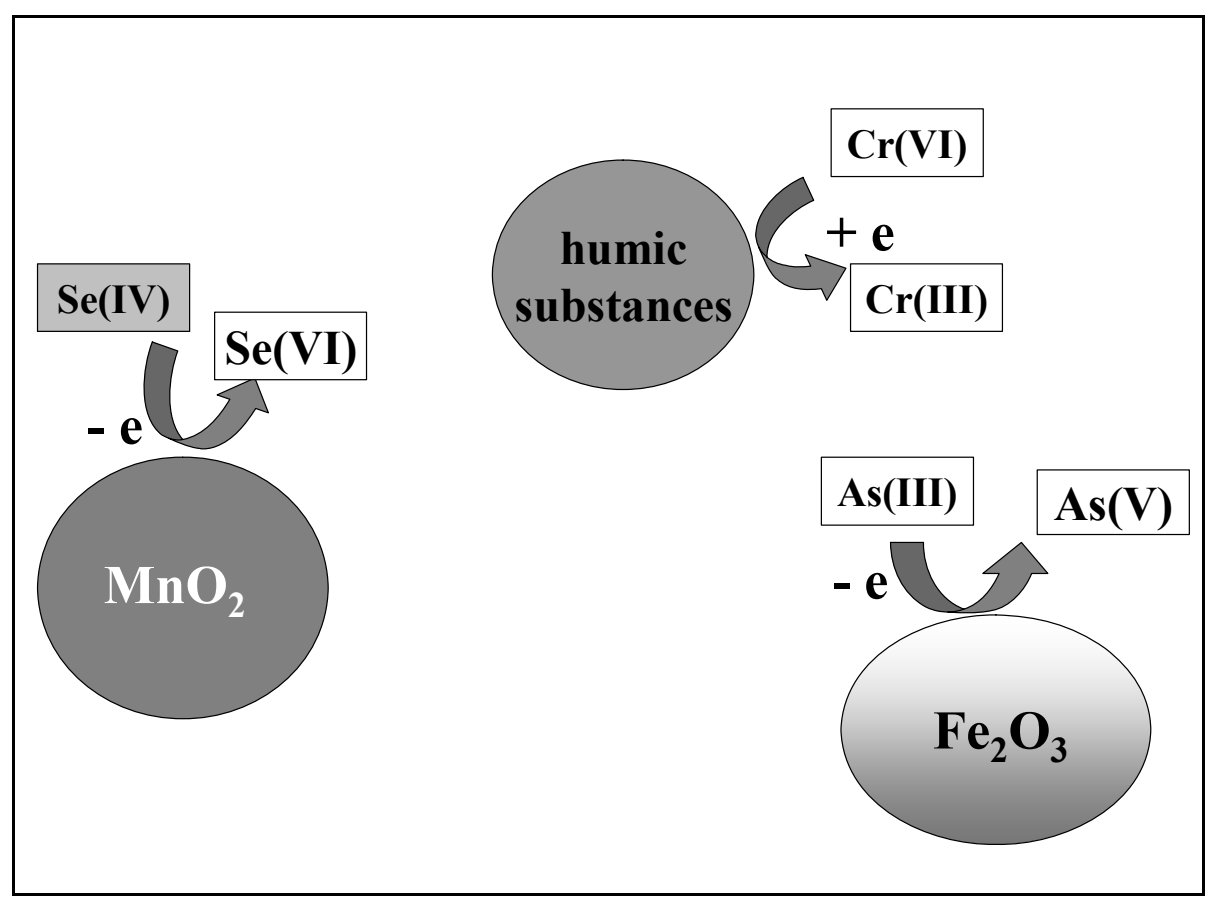

Figure 1. Possible abiotic redox processes occurring on the surfaces of humic substances and $\mathrm{Fe}-$ and $\mathrm{Mn}$ - oxides.

phyllosilicates, indicating that specific sorption and other complexation processes are the dominant binding mechanisms.

Except for some noncrystalline minerals that have very high specific surface charge density with highly reactive sites, organic matter appears to have the greatest capacity for sorption of trace elements in cationic form.

Humic substances contain a large number of complexing sites, hence they behave as a natural "multiligand" complexing system (Buffle, 1988). The high selectivity degree of soil organic matter for most trace elements in cationic form indicates that they form inner-sphere complexes with the functional groups, often forming an internal five- or sixmember ring on structures (Senesi, 1992; Senesi and Loffredo, 1998; Huang and Germida, 2002; Sparks, 2003).
Complexation reactions have the following effects: i) metal ions are prevented from being precipitated; ii) complexing agents can act as carriers for trace elements in soil solution; iii) their toxicity is often reduced by complexation. The stability constant $(\mathrm{K})$ of trace element complexes with humic acids increases with increasing $\mathrm{pH}$ and decreasing ionic strength.

Unlike phyllosilicates, the variable charge minerals (crystalline and short range ordered $\mathrm{Fe}-$, $\mathrm{Al}-$, Mn-oxides, allophanes, imogolite) strongly retain trace heavy metals for their dependency on $\mathrm{pH}$. On these materials a hydroxylated or hydrated surface, positive or negative charge is developed by sorption or desorption of $\mathrm{H}^{+}$or $\mathrm{OH}^{-}$ions (Figure 2). The $\mathrm{pH}$ at which the net variable charge on the surfaces of these components is zero is called the point of zero charge 


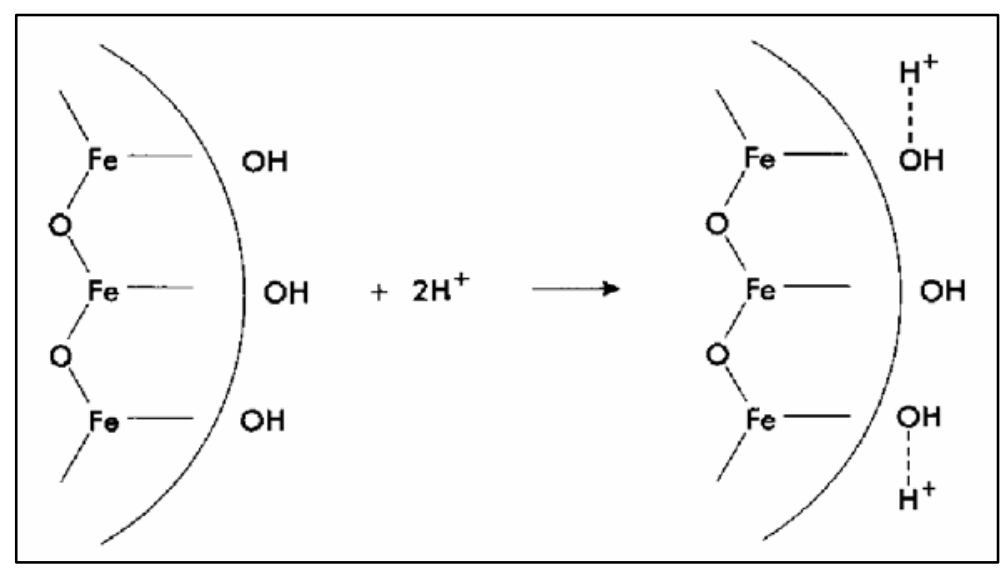

Figure 2. Acid-base reactions of surface hydroxyl Fe-oxide- water interfaces.

(PZC). The reported PZC of Fe-oxides range from $\mathrm{pH} 7.0$ to 9.5 , whereas that of Al-oxides ranges from $\mathrm{pH} 8.0$ to 9.2 . (Hsu, 1989; Cornell and Schwertman, 1996; Violante et al., 2005).

Variable charge minerals selectively sorb polyvalent cations, even when their surfaces are positively charged (solution $\mathrm{pH}$ values lower than the point of zero charge $[\mathrm{PZC}]$ of the sorbent). Most transition cations $(\mathrm{Pb}, \mathrm{Cu}, \mathrm{Cr}, \mathrm{Ni}, \mathrm{Co}, \mathrm{Zn}$, $\mathrm{Al}, \mathrm{Fe}, \mathrm{Mn})$ are often sorbed more strongly than alkaline earth cations. Spectroscopic techniques such as electron spin resonance (ESR) and Extended X-ray Absorption Fine Structure Spectroscopy (EXAFS) have been used for the identification of metal complexes at the surfaces of $\mathrm{Al}, \mathrm{Fe}$ or $\mathrm{Mn}$ oxides, silicate clays and soil organic matter.

Sorption of metal cations increases by increasing $\mathrm{pH}$. Sorption, which rises from 0 to $100 \%$ of the added amount over a narrow region of $1-2 \mathrm{pH}$ units, is termed as "sorption edge". The $\mathrm{pH}$ at which $50 \%$ of the total sorption has occurred is called $\mathrm{pH}_{50}$. The lower the $\mathrm{pH}_{50}$ of a trace element for a sorbent, the stronger is the element-surface complex (Kinniburgh and Jackson, 1976, 1981; Sparks, 2003;
Violante et al., 2003; 2008). Experiments with various synthetic $\mathrm{Fe}, \mathrm{Al}$ and $\mathrm{Mn}$ oxides showed that the affinity of trace elements for Mn oxide was usually much greater than that for $\mathrm{Fe}$ or $\mathrm{Al}$ oxides. However, the nature, crystallinity size of the crystals, surface charge of metal oxides and mixed metal oxides (e.g., Fe$\mathrm{Al}$ oxides) also play an important role in the sorption selectivity of trace elements in cationic form (Kinniburg and Jackson, 1976; McBride, 1982; Violante et al., 2003; Sparks, 2003; Violante et al., 2008).

Evidence on the sorption of trace elements on microorganisms have been reported. Biosorption can be defined as the microbial uptake of soluble and insoluble organic and inorganic metal species by physico-chemical mechanisms such as sorption and, in living cells, metabolic activity may influence this process because of changes in $\mathrm{pH}, \mathrm{E}_{\mathrm{h}}$, organic and inorganic nutrients and metabolite excretion. Biosorption can also be a prelude for the formation of stable minerals. Cationic metal species can also be accumulated within cells via membrane transport systems of varying affinity and specificity (Gadd, 2008). Free-living bacteria and their extra-cellular macromolecular products 
(e.g. fibrils) can accumulate trace elements and may have mineral coatings with bound metals on their surfaces (Beveridge, 1989a and 1989b; Jackson and Leppard, 2002 and references there in). All microorganisms contain biopolymers such as proteins, nucleic acids, and polysaccharides which provide reactive sites for binding metal ions. Cell surfaces of all bacteria are negatively charged containing different types of negatively charged functional groups, such as carboxyl, hydroxyl and phosphoryl that can adsorb metal cations, and retain them by mineral nucleation.

Intact bacterial cells, live or dead, and their products are also highly efficient in accumulating both soluble and particulate metals forms. Therefore, bacteria play an important role in the speciation, fate and transport of metals, metalloids and radionuclides in soil and associated environments. Lopez et al. (2000) reported the following affinity order for the surfaces of microorganisms: $\mathrm{Ni} \gg \mathrm{Hg}$ $>\mathrm{U}>\mathrm{As}>\mathrm{Cu}>\mathrm{Cd}>\mathrm{Co}>\mathrm{Cr}>\mathrm{Pb}$.

Biosorption is a fast and reversible process for removing toxic metal ions from solution. Many environmental factors influence the chemical reactivity of the binding sites on bacterial cell surfaces and the subsequent biosorption of metals. These factors include $\mathrm{pH}$, ionic strength, temperature, and the presence of other metals and organic compounds. The ability of bacteria to accumulate toxic metals also varies with cell age.

Many factors such as $\mathrm{pH}$, surface properties of the sorbents, number of sites available for sorption, nature and charge of $\mathrm{Me}-\mathrm{L}$ species in solution influence trace element sorption onto soil components in the presence of inorganic and biological ligands. In rhizospheric soils, the amount of natural organic compounds is much higher than in bulk soil at the soil-root interface. In fact, rhizosphere $\mathrm{C}$ flow has been estimated to account for a large fraction of plant primary production. Up to $20 \%$ of the C assimilated through photosynthesis can be released from roots. In the rhizosphere, root exudates comprise both high and low-molar-mass substances released by the roots. The most important highmolecular-mass compounds are mucilage, polysaccharides and ectoenzymes, whereas the main constituents of the low molecular mass root exudates are carbohydrates, organic acids, amino acids, peptides and phenolics. Microorganisms produce a number of extracellular metabolites that can complex metals in solution, including polysaccharides, pigments, organic acids and siderophores. Citric and oxalic acids are released by free-living and mycorrhizal fungi, lichens and plant roots.

Inorganic and organic ligands (e.g., organic acids) which form strong complexes with ions of metals usually prevent or reverse their association with negatively charged sorbents, as phyllosilicates, by forming stable dissolved or dispersed negatively charged complexes with the cations. In contrast, the presence of certain (phyto)siderophores produced by microorganisms and phytosiderophores exuded by plants may promote the formation of positive complexes and, consequently, the sorption of trace elements onto phyllosilicates (Violante et al., 2008; see their Figures 5.3 and 5.4).

The processes, which affect the sorption of trace element cations onto variable charge minerals in the presence of complexing agents, are particularly complex and are different from those onto phyllosilicates (Violante et al., 2008). Recently, Perelomov et al. (2010) studied the influence of selected low molecular mass organic ligands on $\mathrm{Cu}$ and $\mathrm{Pb}$ sorption onto a goethite.

Figure 3 shows $\mathrm{Cu}$ and $\mathrm{Pb}$ amounts (25 mmol added per $\mathrm{kg}$ ) sorbed at $\mathrm{pH} 5.0$ in 
the presence of oxalic (OX), citric (CT) or glutamic (GL) acid. By increasing the initial organic ligand/Me molar ratio (r) from 0 to 10 , the sorption of both metals on the iron oxide initially increased and then decreased or remained constant, as referred to their sorption when added alone $(r=0)$. In the presence of oxalic acid, the sorption of $\mathrm{Cu}$ on the surfaces of goethite increased until 2 and then decreased. Citric acid showed a similar effect on $\mathrm{Cu}$ sorption, but fixed $\mathrm{Cu}$ amounts were lower at $\mathrm{CT} / \mathrm{Cu}$ molar ratio of 2 and 4. Glutamic acid had the lowest effect on the sorption of this element onto goethite. Cupper sorption sharply increased at $\mathrm{r}=1$ and then grew very slowly. However, at $\mathrm{R}>6$ a greater $\mathrm{Cu}$ amount was sorbed in the presence of glutamic acid than in the presence of oxalic or citric acid (Figure 3A). Lead showed a similar behavior, but its sorption was lower than that of $\mathrm{Cu}$ on this sorbent (Figure 3B).
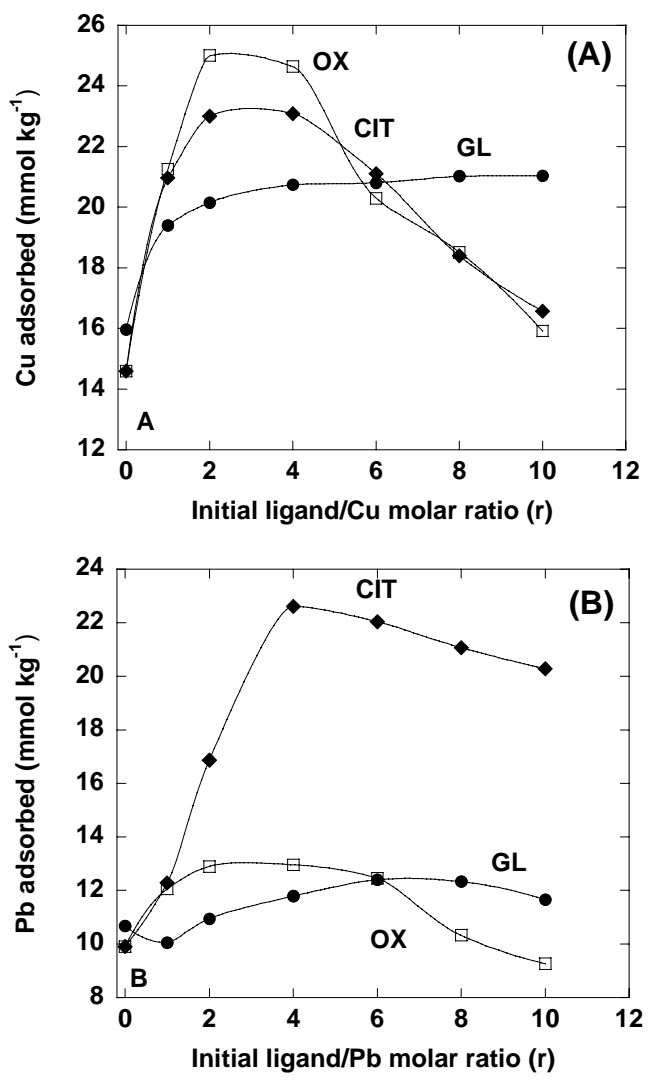

Figure 3. Adsorption of $\mathrm{Cu}(\mathrm{A})$ and $\mathrm{Pb}(\mathrm{B})$ on goethite at $\mathrm{pH} 5$ in the presence of increasing concentrations of Oxalic (OX), citric (CT) or glutamic acid (initial ligand/Cu or $\mathrm{Pb}$ molar ratio from 0 to $10 ; 25 \mathrm{mmol}$ of $\mathrm{Cu}$ or $\mathrm{Pb}$ added per $\mathrm{kg}$ of goethite). 
These findings indicate that heavy metals complexed with organic ligands have a greater affinity for the surfaces of a sorbent at certain ligand/metal molar ratio and promote the formation of ternary complexes (McBride, 1989). The complexes affinity is affected by the nature and concentration of the cation and the organic ligand involved in the complexes, mineralogy and surface properties of the sorbent and $\mathrm{pH}$ (Violante et al., 2008, and references therein). In the presence of high concentrations of negative charged organic ligand, the sorption of heavy metals decreases clearly because different processes, which prevent the metal sorption, may occur. Large amounts of these organic ligands may either occupy many sorption sites on the iron mineral, which are then not available for the metals, or may favor complexation in solution and metal desorption relative to ternary complex formation. In other words, large excess of chelating ligands may shift the equilibrium in favor of soluble metal complexes and, consequently, the ternary complex is destabilized.

\section{Competitive sorption of heavy metals in absence or presence of chelating ligands}

Heavy metals compete for sorption sites onto soil components (Violante et al., 2003; 2005, 2008). Experiments on the competitive $\mathrm{Cu}$ and $\mathrm{Zn}$ sorption were carried out on a ferrihydrite, a humic acidlike sample (POL), and a $\mathrm{Fe}(\mathrm{OH}) x-\mathrm{POL}$ complex (Capasso et al., 2004). On POL as well as on ferrihydrite, $\mathrm{Cu}$ was sorbed more selectively than $\mathrm{Zn}$. In the presence of equimolar $\mathrm{Zn}$ concentrations, the sorbed $\mathrm{Cu}$ amounts were only slightly reduced when compared with the amounts sorbed in the absence of $\mathrm{Zn}$. Conversely, the $\mathrm{Cu}$ presence strongly reduced $\mathrm{Zn}$ sorption. A similar trend was observed using a $\mathrm{Fe}(\mathrm{OH}) x-\mathrm{POL}$ complex as sorbent, but the quantities of sorbed $\mathrm{Cu}$ and $\mathrm{Zn}$ on this complex were much lower than those fixed on the humic acid-like sample.

Time of reaction, surface coverage, sequence of addition of sorbates have also a great influence on the competitive sorption between trace elements and organic and inorganic ligands. Most competitive sorption studies have been carried out adding the ions contemporaneously. However, it is more likely that the ions will come in contact with a sorbent sequentially in natural environments, i.e., the solid is exposed to one ion first, with the second ion coming in contact with a solid at a later time. The sorption of metals and metalloids is strongly affected by the order of addition of organic and inorganic ligands and trace elements on the sorbents. It has been demonstrated that larger amounts of selected heavy metals $(\mathrm{Pb}, \mathrm{Cu})$ were sorbed when chelating organic anions (oxalate, tartrate) were added before or after the metals as referred to the systems where the heavy metals were added as a mixture with the organic ligands or alone (Violante et al. 2003).

Competition in sorption between two or three heavy metals on soil components take into account attention in the last years (Violante et al., 2008 and references there in). Recently, Perelomov et al., 2010 studied the competition in sorption between $\mathrm{Pb}$ and $\mathrm{Cu}$ in the absence or presence of oxalic acid. Figure 4 shows the effect of increasing $\mathrm{Pb}$ concentrations (25 mmol added per $\mathrm{kg}$ ) on $\mathrm{Cu}$ sorption (initial $\mathrm{Pb} / \mathrm{Cu}$ molar ratio [R] ranging from 0 to 10 ) at $\mathrm{pH} 5.0$ either in the absence or presence of oxalic acid. Oxalic acid (25 mmol $\mathrm{kg}^{-1}$ ) was added as a mixture with the heavy metals $(\mathrm{Cu}+\mathrm{Pb}+\mathrm{OX}$ systems $)$ or one hour before $\mathrm{Cu}+\mathrm{Pb}$ addition $(\mathrm{OX} / / \mathrm{Cu}+\mathrm{Pb}$ systems $)$. 


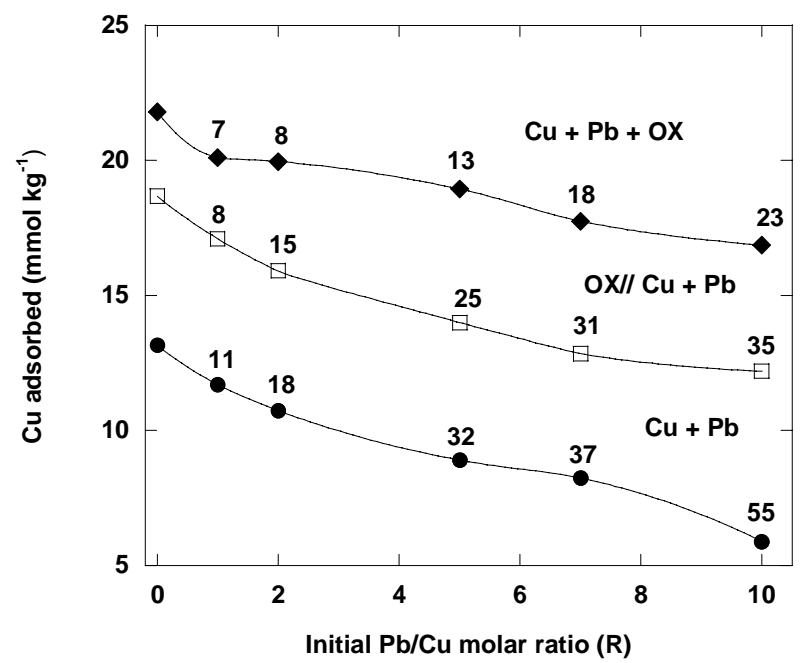

Figure 4. $\mathrm{Cu}$ Adsorption on goethite in the presence of increasing of $\mathrm{Pb}$ concentration (initial $\mathrm{Pb} / \mathrm{Cu}$ molar ratio (R) ranging from 0 to 10 ). $25 \mathrm{mmol}$ of $\mathrm{Cu}$ was added per $\mathrm{kg}$ of goethite).

Lead strongly inhibited $\mathrm{Cu}$ sorption, but its inhibition was affected by the initial $\mathrm{Pb} / \mathrm{Cu}$ molar ratio and presence of oxalic acid. In the absence of oxalic acid $(\mathrm{Pb}+$ $\mathrm{Cu}$ systems), the $\mathrm{Pb}$ inhibition in preventing $\mathrm{Cu}$ sorption increased from $11 \%$ at $\mathrm{R}=1$ to $55 \%$ at $\mathrm{R}=10$ (numbers reported on the curves in Figure 4 indicate the inhibition in percentage). The presence of the organic ligand enhanced $\mathrm{Cu}$ sorption when added together, more than before the trace elements. In fact, the increase of $\mathrm{Cu}$ sorption ranged from 34 to $43 \%$ in $\mathrm{Cu}+\mathrm{Pb}+\mathrm{OX}$ systems and from 18 to 25 in $\mathrm{OX} / / \mathrm{Cu}+\mathrm{Pb}$ systems. In the presence of oxalic acid, $\mathrm{Pb}$ was less efficient in preventing $\mathrm{Cu}$ sorption than in the absence of the organic ligand, but it affected $\mathrm{Cu}$ fixation more in $\mathrm{OX} / / \mathrm{Cu}+\mathrm{Pb}$ (from 8 to $35 \%$ ) than $\mathrm{Cu}+\mathrm{Pb}+\mathrm{OX}$ systems (from 7 to $23 \%$ ) (not shown).

\section{Desorption of trace elements in cationic} form

Desorption studies of heavy metals in cationic form have shown biphasic reaction processes, a fast reaction followed by a slow reaction (Sparks, 1990).

The presence of inorganic and organic ligands has a significant impact on the desorption of trace elements from soils or soil components. Krishnamurti et al. (1997) demonstrated that LMMOLs have the ability to desorb $\mathrm{Cd}$ from soils, with malate, fumarate, and succinate being the most effective ligands. Helal (2006) found that small $\mathrm{Pb}$ portions less than $16 \%$ of the amounts previously sorbed onto $\mathrm{Fe}$ - or Al-precipitates were replaced at $\mathrm{pH} 7.0$ by LMMOLs (oxalate, citrate and tannate). Lower amounts were desorbed from Feoxides. Desorption increased as sorption density rose and $\mathrm{pH}$ decreased.

Another important aspect that influences desorption of heavy metals in cationic form is the residence time effect. Some researchers found that trace elements reacted with metal oxides and pyrophyllite over longer times resulted in either irreversible or reversible sorption mechanisms. Helal (2006) showed that as 
residence time sorbed $\mathrm{Pb}$, in particular at $\mathrm{pH} 7.0$ it was nearly irreversible over a desorption period of $24 \mathrm{~h}$. Violante et al. (2003) studied residence time effect on $\mathrm{Zn}$ sorption onto ferrihydrite in the presence of copper. As copper has a greater affinity than zinc for the surfaces of ferrihydrite, $\mathrm{Cu}$ was added from 1 to 336 hours after $\mathrm{Zn}$ at a $\mathrm{Zn} / \mathrm{Cu}$ molar ratio of 2. $\mathrm{Zn}$ sorption increased, especially when $\mathrm{Cu}$ was added 6 to 336 hours after $\mathrm{Zn}$. A possible explanation of these findings is that trace elements initially sorbed on the surfaces of variable charge minerals slowly form precipitates with time and/or penetrate into micropores of the sorbents.

\section{Sorption of trace elements in anionic form}

Trace elements which exist in anionic form are mainly sorbed at reactive sites of metal oxides and allophanes and at the edges of phyllosilicates (Kampf et al. 2000; Violante et al. 2008). Sorption of anions onto variable charge minerals and soils varies with $\mathrm{pH}$. With increasing $\mathrm{pH}$, within a certain range, sorption decreases (due to a decrease of positive charge of minerals) or increases to a maximum close to $\mathrm{pKa}$ for anions of monoprotic conjugate acids and then decreases.

Anions may be sorbed specifically or nonspecifically. Ligands which are specifically sorbed replace $\mathrm{OH}^{-}$or $\mathrm{OH}_{2}$ groups from the surfaces of variable charge minerals. These reactions are promoted at a low $\mathrm{pH}$, which causes $\mathrm{OH}^{-}$ groups to accept protons, being $\mathrm{OH}_{2}$ group an easier ligand to displace than $\mathrm{OH}^{-}$Specific sorption is also termed "inner-sphere sorption" as reported above. (Violante et al., 2008).

Trace elements, which form innersphere complexes, are molybdate, arsenate, arsenite (only onto Fe-oxides) and selenite. Particularly, arsenate may form different surface complexes on inorganic soil components: monodentate, bidentate-mononuclear and bidentatebinuclear complexes in different proportion depending on $\mathrm{pH}$ and surface coverage (Fendorf et al. 1997; O'Reilly et al. 2001). Several studies have suggested that arsenate is sorbed more than arsenite in a wide range of $\mathrm{pH}$. However, literature studies have found that arsenite is sorbed more than arsenate on ferrihydrite. The sorption mechanisms of chromate are unclear. Zachara et al. (1989) suggested that chromate forms an outer-sphere complex on the surfaces of $\mathrm{Fe}$ and $\mathrm{Al}$ oxides. However, spectroscopic studies have shown that chromate forms inner-sphere complexes on goethite (Fendorf et al. 1997). This anion has a smaller shared charge than arsenite and arsenate, creating a weaker bond on sorption (McBride, 1994) and consequently, exhibits a steeper reduced sorption at near neutral $\mathrm{pH}$ values than that of arsenate (Grossl et al. 1997). However, where more than one type of surface species is present, XAS bulk will detect only the primary (or average) type of surface product/species in the bulk sample (i.e., sums over all geometric configurations of the target atom). Consequently, while it may be concluded that the primary surface complex is innersphere, this does not mean that outersphere complexation is not occurring. Recently, through the use of X-ray scattering measurements to study metal(loid) binding on single crystal surfaces, Catalano et al. (2008) showed that arsenate surface complexation was bimodal, with sorption occurring simultaneously as inner- and outer-sphere species.

Martin et al. (2009) showed that arsenate and arsenite were differently sorbed onto different minerals (Figure 5). Arsenate showed a higher affinity for minerals containing iron or manganese than on minerals containing aluminum 
(Violante and Pigna, 2002). Pigna et al. sorbed more than arsenate, particularly in (unpublished data) found that arsenite is alkaline $\mathrm{pH}$ on ferrihydrite (Figure 6).
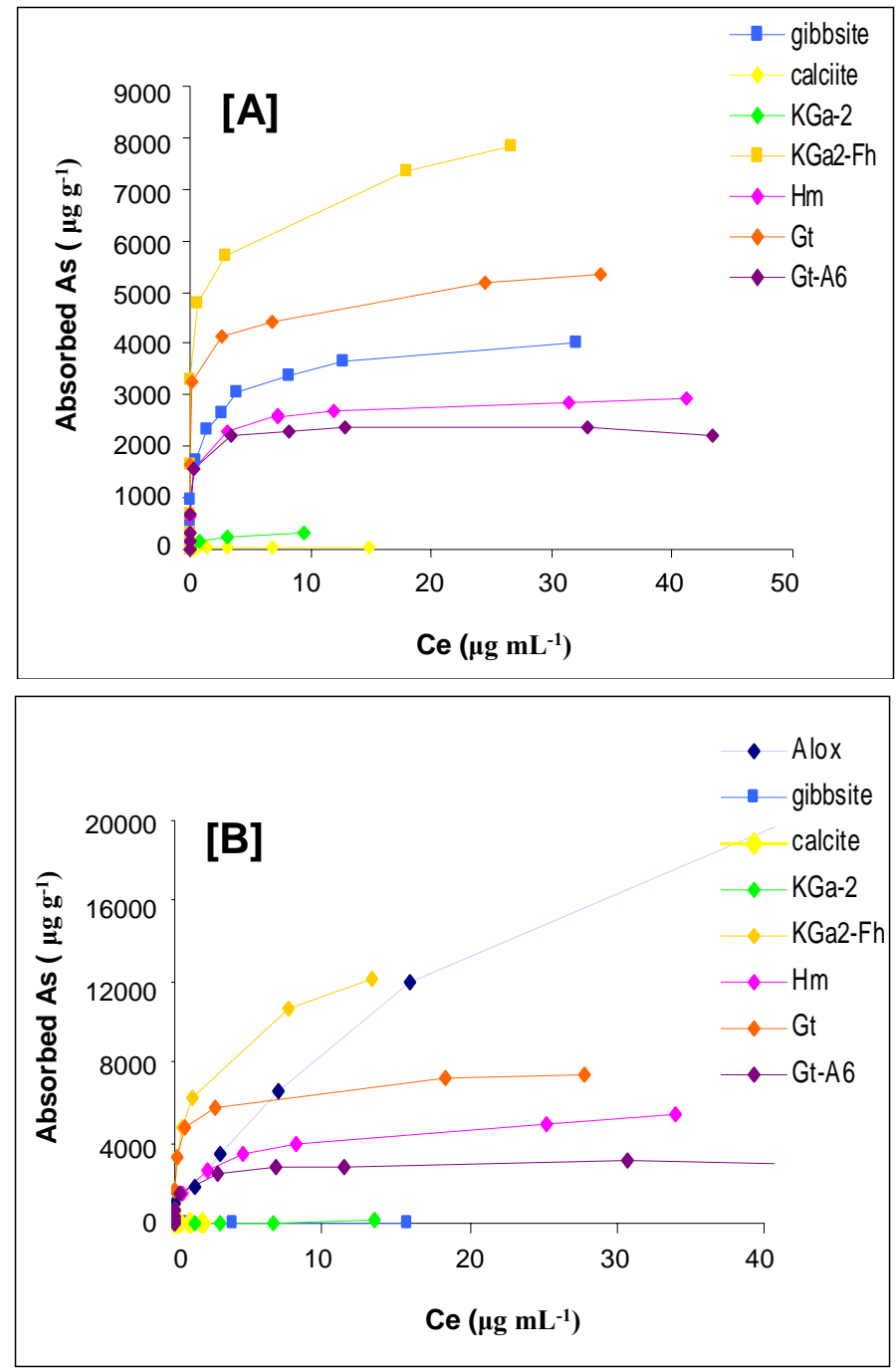

Figure 5. Adsorption of $\mathrm{As}(\mathrm{V})[\mathrm{A}]$ and $\mathrm{As}(\mathrm{III})[\mathrm{B}]$ on different substrates. 


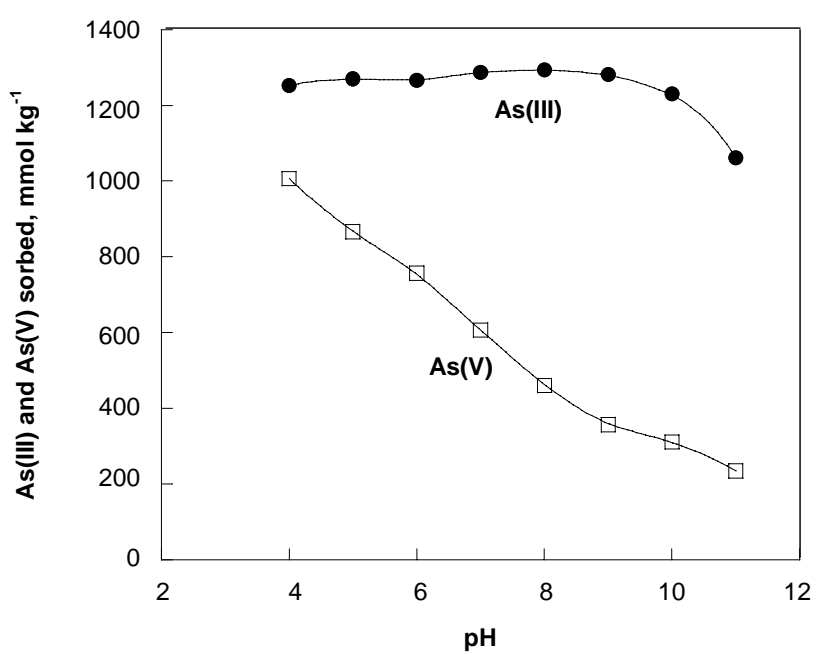

Figure 6. $\mathrm{pH}$ influence on the $\mathrm{As}(\mathrm{V})$ and $\mathrm{As}(\mathrm{III})$ adsorption onto ferrihydrite

\section{Competitive sorption}

The competitive sorption between trace elements in anionic form has received attention. However, a systematic investigation of the relative competition for sorption onto variable-charge minerals and soils among various anions with different binding affinities is rather limited.

Manning and Goldberg (1996) studied $\mathrm{pH}$ effects and competing molybdate and arsenate ions onto goethite and gibbsite. Molybdate at $50 \%$ of surface coverage decreased the sorption of arsenate only at $\mathrm{pH}<6.0$, whereas arsenate reduced molybdate sorption within a wider $\mathrm{pH}$ range (2.0 to 9.0 for goethite and 2.0 to 8.0 for gibbsite). Their data suggested that arsenate occupies a fraction of the $\mathrm{pH}-$ dependent molybdate sorption sites on both goethite and gibbsite and that another distinct fraction of sites has a higher affinity for molybdate than arsenate at low $\mathrm{pH}$.

Recently, Pigna et al. (2010) carried out experiments on the competition in sorption between $\mathrm{As}(\mathrm{III})$ or $\mathrm{As}(\mathrm{V})$ with organic and inorganic ligands onto ferrihydrite. Table 1 shows the amounts of $\mathrm{As}(\mathrm{III})$ and $\mathrm{As}(\mathrm{V})$ sorbed at $6.0 \mathrm{pH}$ on ferrihydrite in the presence of inorganic anions (sulfate, selenate and selenite) and organic (oxalate, malate, tartrate and citrate) added simultaneously with As(III) or $\mathrm{As}(\mathrm{V})$ at the initial ligand / As (III) or $\mathrm{As}(\mathrm{V})$ molar ratio $=1$. The parameter used for comparing the behaviour of the various anions to compete with $\mathrm{As}(\mathrm{III})$ or $\mathrm{As}(\mathrm{V})$ was the efficiency of the ligands in preventing the sorption of the metalloid calculated according to the following expression:

Efficiency $=[($ As added alone - As sorbed in the presence of a ligand) / As alone] x 100

In respect to the behaviour of individual inorganic anions to compete with arsenic for sorption sites on ferrihydrite the following sequence was observed:

$$
\mathrm{SeO}_{3} \gg \mathrm{SeO}_{4} \approx \mathrm{SO}_{4}
$$


In particular, sulphate and selenate did not compete with As(V) or showed a negligible capacity to compete with As(III), whereas selenite strongly competed with both As(III) and As(V) (Table 1).

The organic anions had a great influence in inhibiting As sorption according to this sequence:

$$
\text { Citrate }>\text { Tartrate } \approx \text { Malate }>\text { Oxalate }
$$

The greater capacity of citrate to compete with arsenic compared with other organic ligands must be attributed to its high capacity to be sorbed on the surfaces of ferrihydrite and to form strong complexes with Fe.

\section{Desorption of trace elements in anionic form}

In contrast to sorption studies, relative little information is available on desorption of trace elements in anionic forms from soil or soil components (Violante et al., 2008). Desorption of metalloids from soils is particularly affected by the residence time. O Really et al. (2001) studied the residence time effect on arsenate desorption by phosphate at a 3- phosphate/arsenate molar ratio from goethite at different $\mathrm{pH}$ values. Initially, the desorption of arsenate was very fast $(35 \%$ of $\mathrm{As}(\mathrm{V})$ desorbed within $24 \mathrm{~h}$ ), and then it slowed down.

Table 1. Influence of organic and inorganic ligands on the adsorption of As(III) and $\operatorname{As}(\mathrm{V})$ on ferrihydrite

\begin{tabular}{|c|c|c|c|c|c|}
\hline Ligands & $\begin{array}{c}\text { As(III) sorbed } \\
\text { ligand/As(III) }=1 \\
\mathrm{mmol} \mathrm{kg}^{-1}\end{array}$ & $\begin{array}{c}\text { Efficiency } \\
\\
\% \\
\end{array}$ & Ligands & $\begin{array}{c}\text { As(III) sorbed } \\
\text { ligand/As(V) }=1 \\
\mathbf{m m o l ~ k g}^{-1} \\
\end{array}$ & Efficiency \\
\hline $\mathrm{SO}_{4}$ & 954.4 & 1.5 & $\mathrm{SO}_{4}$ & 600.0 & 0 \\
\hline $\mathrm{SeO}_{4}$ & 948.2 & 2.2 & $\mathrm{SeO}_{4}$ & 600.0 & 0 \\
\hline $\mathrm{SeO}_{3}$ & 753.1 & 22.3 & $\mathrm{SeO}_{3}$ & 465.0 & 22.5 \\
\hline Ox & 893.4 & 7.8 & Ox & 591.0 & 1.5 \\
\hline Mal & 839.0 & 13.4 & Mal & 536.4 & 10.6 \\
\hline Tar & 837.4 & 13.6 & Tar & 543.0 & 9.5 \\
\hline Cit & 778.4 & 19.7 & Cit & 495.0 & 17.5 \\
\hline As(III) alone & 969.1 & - & $\mathrm{As}(\mathrm{V})$ alone & 600.0 & - \\
\hline
\end{tabular}

Total desorption increased with time, reaching about $65 \%$ total desorption after five months. O'Reilly et al. (2001) did not find significant role of residence time in preventing arsenate desorption. In contrast, Arai and Sparks, (2002) demonstrated than the longer the residence time (3 days to 1 year), the greater the decrease in arsenate desorption by phosphate from a bayerite. Similar results, were found by Pigna et al. (unpublished data) who studied the effect of residence time on arsenate desorption by phosphate (phosphate/arsenate molar ratio of 3) from an Andisol sample containing $42 \%$ of allophanic materials (Vacca et al., 2002). The amounts of arsenate desorbed by phosphate after one week decreased from $53 \%$ to $35 \%$ and $22 \%$ when phosphate was added 1,5 , or 15 days, respectively, after arsenate addition (Figure 7). 


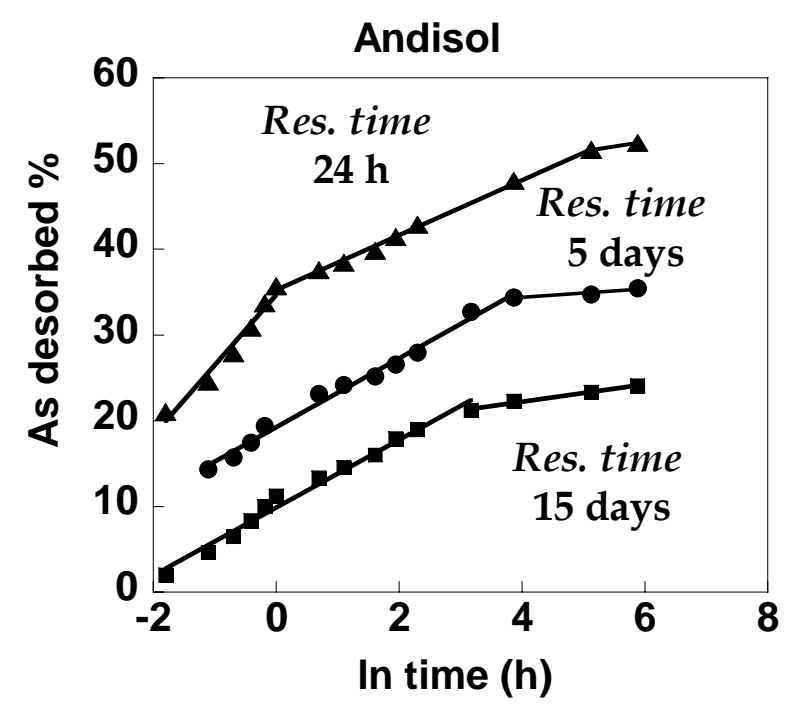

Figure 7. Influence of residence time on arsenate desorption by phosphate from an Italian Andisol. Phosphate/arsenate molar ratio $=3$.

\section{CHEMICAL FRACTIONATION AND BIOAVAILABILITY OF HEAVY METALS AND METALLOIDS}

The biogeochemical cycle of heavy metals and metalloids has been greatly accelerated by human activities. Accumulation of metal ions and metalloids in different compartments of the biosphere, and their possible mobilization under environmentally changing conditions induce a perturbation of both the structure and function of the ecosystem and might cause adverse health effects to biota (Fedotov and Mirò, 2008). Heavy metals and metalloids enter an agroecosystem through both natural and anthropogenic processes. Some soils have been found to have a high background of some trace elements, which are toxic to plants and wild life, due to extremely high concentrations of these elements in the parent materials. Anthropogenic processes include inputs of heavy metals through use of fertilizers, organic manures, and industrial and municipal wastes, irrigation, and wet and/or dry deposits. These processes contribute with variable amounts of heavy metals to the agroecosystem.

Only a small portion of heavy metals and metalloids in soil is bioavailable. The mobility and availability of these pollutants are controlled by many chemical and biochemical processes such as precipitation-dissolution, sorptiondesorption, complexation-dissociation, and oxidation-reduction. Not all the processes are equally important for each element, but all of them are affected by soil $\mathrm{pH}$ and biological processes. Therefore, it is crucial to understand some major reactions in soils that control the release of a specific trace element in the soil and the environment in order to overcome problems related to deficiency and contamination of these elements. 
The determination of total soil metal content alone is not a good measure of bioavailability and not a very useful tool to quantify contamination and potential environmental and human health risks. Total concentrations of metals in soils are a poor indicator of metal toxicity since metals exist in different solid-phase forms that can vary greatly in terms of their bioavailability (Krishnamurti et al., 1995a and 1995b; Krishnamurti et al., 1996; Krishnamurti and Naidu, 2002, 2008; Huang and Gobran, 2005). Most regulations or guidelines used for protecting soil from metal pollution (to set maximum permissible metal concentrations used for definition of contaminated sites, for setting remediation clean-up goals, and for limiting loading of metals to soils in fertilizers and wastes) are still based on assessing the total concentration of metal present in the soil. Recently, some countries have started to introduce the concept of bioavailability in their regulations concerning environmental protection and remediation. The bioavailability of heavy metals and metalloids, their biological uptake, and their eco-toxicological effects on the soil biota can be better understood in terms of their chemical speciation. The mobility and bioavailability, and hence potential toxicity of metal in the soil depend on its concentration in soil solution, the nature of its association with other soluble species, and soil ability to release the metal from the solid phase to replenish that removed from soil solution by the plants (Krishnamurti and Naidu, 2002; Huang and Gobran, 2005; Krishnamurti et al., 2007).

The identification and quantification of metals associated with predefined phases or soil components is defined as "fractionation analysis" according to JUPAC recommendation (Templeton et al., 2000). The extractants used in the sequential extraction procedures (SEPs) are intended to simulate conditions under which metals associated with certain mineralogical phases can be released (Fedotov and Mirò, 2008). Fractionation of heavy metal cations into operationally defined forms under the sequential action of given reagents with increasing aggressiveness is a common approach for distinguishing various species of trace elements according to their physicochemical mobility and potential bioavailability (Table 2) (Ure and Davison, 2001; Hlavay et al. 2004; Fedotov and Mirò, 2008). Fractionation of elements existing in anionic forms needs obviously a specific sequence of leaching reagents, as discussed later.

Sequential extraction schemes for metal partitioning in environmental solid samples have recently been summarized in a comprehensive review by Filgueiras et al. (2002) and in a JUPAC technical report by Hlavay et al. (2004).

A more sophisticated SEP, which significantly improved the specificity and efficiency of extraction, by a carefully designed combination of various extractants in order to identify the specific species contributing to bioavailability was proposed by Krishnamurti et al. (1995a and $\mathrm{b}$ ).

The differentiation of the metalorganic-complex-bound metal species, as distinct from the other organically bound species was the innovation in the selective sequential extraction scheme suggested by these authors. The particulate-bound metal species in soils were fractionated as exchangeable, carbonate-, metal-organic complex, easily reducible metal oxide-, organic material, amorphous mineral colloid, crystalline Fe oxide-bound and residual. The metal-organic complexbound was selectively extracted using 0.1 $\mathrm{M}$ sodium pyrophosphate $(\mathrm{pH} 10)$ as the extractant in the sequential extraction scheme. 
Table 2. Operationally defined fraction and corresponding extracted components (by Fedotov and Mirò, 2008).

\begin{tabular}{|c|c|c|c|c|}
\hline Defined fraction & $\begin{array}{c}\text { Extracted components } \\
\text { (Possible forms of binding TEs) }\end{array}$ & $\begin{array}{l}\text { Physicochemical } \\
\text { mobility }\end{array}$ & $\begin{array}{c}\text { Potential } \\
\text { bioavailability }\end{array}$ & $\begin{array}{l}\text { Common } \\
\text { extractants }\end{array}$ \\
\hline Water soluble & Free ions & Mobile & Easily available & Deionized water \\
\hline Exchangeable (A) & $\begin{array}{l}\text { Exchangeable ions (metals retained by } \\
\text { weak electrostatic interactions) }\end{array}$ & Mobile & Easily available & $\begin{array}{c}\mathrm{Ca}\left(\mathrm{NO}_{3}\right)_{2}, \mathrm{Mg}\left(\mathrm{NO}_{3}\right)_{2} \\
\mathrm{CaCl}_{2}, \mathrm{MgCl}_{2} \\
\mathrm{CH}_{3} \mathrm{COONH}_{4}\end{array}$ \\
\hline Acid soluble (B) & $\begin{array}{l}\text { Carbonates (for noncalcareous soils: } \\
\text { other specifically adsorbed forms of } \\
\text { TEs) }\end{array}$ & Easily mobilizable & Easily available & $\begin{array}{c}\mathrm{CH}_{3} \mathrm{COOH}, \mathrm{CH}_{3} \mathrm{COONa} \\
(\mathrm{pH}<6.0)\end{array}$ \\
\hline Easily reducible $(\mathrm{C})$ & Mn oxyhydroxides & Readily mobilizable & Readily available & $\mathrm{NH}_{2} \mathrm{OH} \cdot \mathrm{HCl}$ \\
\hline Easily oxidizable (D) & Metal-organic complexes & Readily mobilizable & Readily available & $\mathrm{K}_{4} \mathrm{P}_{2} \mathrm{O}_{7}, \mathrm{Na}_{4} \mathrm{P}_{2} \mathrm{O}_{7}, \mathrm{NaOH}$ \\
\hline Moderately reducible (E) & Amorphous $\mathrm{Fe}$ (and $\mathrm{Al}$ ) oxyhydroxides & Poorly mobilizable & Poorly available & $\begin{array}{l}\text { Oxalate buffer, } \mathrm{NH}_{2} \mathrm{OH} \cdot \\
\mathrm{HCl}\end{array}$ \\
\hline $\begin{array}{l}\text { Moderately and poorly } \\
\text { oxidizable }(\mathrm{F})\end{array}$ & $\begin{array}{l}\text { Refractory organic compounds and } \\
\text { sulfides }\end{array}$ & Poorly mobilizable & Poorly available & $\mathrm{H}_{2} \mathrm{O}_{2} / \mathrm{CH}_{3} \mathrm{COONH}_{4}$ \\
\hline Poorly reducible $(\mathrm{G})$ & Crystalline $\mathrm{Fe}$ and $\mathrm{Al}$ oxyhydroxides & Poorly mobilizable & Poorly available & $\left(\mathrm{NH}_{4}\right)_{2} \mathrm{C}_{2} \mathrm{O}_{4} /$ ascorbic acid \\
\hline Residual & $\begin{array}{l}\text { Mineral lattice (metals retained within } \\
\text { the crystal structure) }\end{array}$ & Immobile & Unavailable & $\mathrm{HF}, \mathrm{HNO}_{3}, \mathrm{HClO}_{4}$ \\
\hline
\end{tabular}


Later, Krishnamurti and Naidu (2000) modified the sequential extraction scheme developed by Krishnamurti et al. (1995a) sub-fractionating the trace element bound to metal-organic complexes as extracted by $0.1 \mathrm{M}$ sodium pyrophosphate (Table 3). This fraction may contain metal associated with both humic and fulvic acid fractions of soil organic matter which is bound in metal-organic complexes. These authors have shown that the modified sequential extraction scheme consisting of 8 steps of extractions subdivides the metal-organic complexbound $\mathrm{Cd}$ into metal-fulvate complexbound and metal-humate complex-bound $\mathrm{Cd}$. Therefore, the scheme fractionates the solid components into specific "species" with operationally defined binding mechanisms, i.e. exchangeable, specifically sorbed/carbonate-bound, metal-fulvate complex-bound, metalhumate complex-bound, easily reducible metal oxide-bound, organic site-bound, amorphous metal oxide-bound, crystalline $\mathrm{Fe}$ oxide-bound, and residual (aluminosilicate lattice-bound). Their data indicate that the extraction scheme could be used for identifying the specific operationally defined "species" contributing to the bioavailability of the trace element. Details of the extraction scheme are presented in Table 3.

The distribution of solid-phase fractions of $\mathrm{Cu}, \mathrm{Zn}$ and $\mathrm{Cd}$ of a few typical surface soils in_South Australia, was carried out by Krishnamurti and Naidu (2000) following the fractionation scheme reported in Table 3 . The trace elements in these soils were dominantly (on an average $40 \%$ of $\mathrm{Cu}, 52.4 \%$ of $\mathrm{Zn}$ and $33.4 \%$ of $\mathrm{Cd}$ ) associated with the alumino-silicate mineral lattices, identified as residual fraction in the scheme, followed by the fraction associated with organic sites (on an average $32.4 \%$ of $\mathrm{Cu}, 28.0 \%$ of $\mathrm{Zn}$ and
$28.5 \%$ of Cd) (see Krishnamurti and Naidu, 2008; their Figures 11.3 and 11.4).

Mobility and plant uptake of trace elements proceed through the solution phase. However, plant uptake of an element depends not only on its activity in the solution, but also on the relation existing between solution ions and solidphase ions.

Plants take up essential and nonessential elements from soils in response to concentration gradients inducted by selective uptake of ions by roots, or by diffusion of elements in the soil. The accumulation level of heavy metals differs between and within species (Huang and Cunningham, 1996; McGrath et al. 2002). Baker (1981) suggested that plants could be classified into three categories: (1) excluders: those that grow in metal-contaminated soil and maintain shoot concentration at low level up to a critical soil value above which relatively unrestricted root-to-shoot transport result, (2) accumulators: those that concentrate metals in the aerial part, and (3) indicators: the uptake and transport of metals to the shoot is regulated so that internal concentration reflects external levels, at least until toxicity occurs. A number of biochemical reactions occur in plants stressed by heavy metal/metalloids. Most of these reactions are produced by the displacement of protein cationic centres or the increase of reactive oxygen species (Figure 8). Those plants with better ability to adjust to toxicity effects are able to survive in heavy metal/metalloids impacted sites and are better candidates for phytoremediation purposes.

An attempt to understand the importance of solid-phase fractions in assessing phytoavailability of $\mathrm{Cu}, \mathrm{Zn}$ and $\mathrm{Cd}$ using multiple regression analysis was made by Krishnamurti and Naidu (2002). Phytoavailable $\mathrm{Cu}, \mathrm{Zn}$ and $\mathrm{Cd}$ were found 
Table 3. Multi-step selective sequential extraction scheme for fractionation of solid metal phases (Krishnamurti and Naidu, 2000)

\begin{tabular}{|c|c|c|c|}
\hline & Target species & Reagent & $\begin{array}{l}\text { Shaking time } \\
\text { and temperature }\end{array}$ \\
\hline Step 1 & Exchangeable & $10 \mathrm{~mL}$ of $\mathrm{M} \mathrm{NH}_{4} \mathrm{NO}_{3}(\mathrm{pH} 7)$ & $4 \mathrm{~h}$ at $25^{\circ} \mathrm{C}$ \\
\hline Step 2 & Specifically adsorbed & $25 \mathrm{~mL}$ of $\mathrm{M} \mathrm{CH}_{3} \mathrm{COONa}(\mathrm{pH} 5)$ & $6 \mathrm{~h}$ at $25^{\circ} \mathrm{C}$ \\
\hline Step 3 & $\begin{array}{l}\text { Metal-organic complex } \\
\text {-bound }\end{array}$ & $30 \mathrm{~mL}$ of $0.1 \mathrm{M} \mathrm{Na}_{4} \mathrm{P}_{2} \mathrm{O}_{7}(\mathrm{pH} 10)$ & $20 \mathrm{~h}$ at $25^{\circ} \mathrm{C}$ \\
\hline Step 4 & $\begin{array}{l}\text { Easily reducible } \\
\text { Metal oxide-bound }\end{array}$ & $20 \mathrm{~mL}$ of $0.1 \mathrm{M} \mathrm{NH}_{2} \mathrm{OH} . \mathrm{HCl}$ in $0.01 \mathrm{M} \mathrm{HNO}_{3}$ & $30 \mathrm{~min}$ at $25^{\circ} \mathrm{C}$ \\
\hline Step 5 & Organic-bound & $\begin{array}{l}5 \mathrm{~mL} \text { of } 30 \% \mathrm{H}_{2} \mathrm{O}_{2}(\mathrm{pH} 2), 3 \mathrm{~mL} \text { of } 0.02 \mathrm{M} \mathrm{HNO}_{3} \\
3 \mathrm{~mL} \text { of } 30 \% \mathrm{H}_{2} \mathrm{O}_{2}(\mathrm{pH} 2), 1 \mathrm{~mL} \text { of } 0.02 \mathrm{M} \mathrm{HNO}_{3} \\
\text { cool, add } 10 \mathrm{~mL} 2 \mathrm{M} \mathrm{NH}_{4} \mathrm{NO}_{3} \text { in } 20 \% \mathrm{HNO}_{3}\end{array}$ & $\begin{array}{l}2 \mathrm{~h} \text { at } 85^{\circ} \mathrm{C} \\
2 \mathrm{~h} \text { at } 85^{\circ} \mathrm{C} \\
30 \text { min at } 25^{\circ} \mathrm{C}\end{array}$ \\
\hline Step 6 & $\begin{array}{l}\text { Amorphous } \\
\text { mineral colloid-bound }\end{array}$ & $10 \mathrm{~mL}$ of $0.2 \mathrm{M}\left(\mathrm{NH}_{4}\right)_{2} \mathrm{C}_{2} \mathrm{O}_{4} / 0.2 \mathrm{M} \mathrm{H}_{2} \mathrm{C}_{2} \mathrm{O}_{4}(\mathrm{pH} 3)$ & $4 \mathrm{~h}$ at $25^{\circ} \mathrm{C}$ (dark) \\
\hline Step 7 & $\begin{array}{l}\text { Crystalline Fe oxide- } \\
\text {-bound }\end{array}$ & $\begin{array}{l}25 \mathrm{~mL} \text { of } 0.2 \mathrm{M}\left(\mathrm{NH}_{4}\right)_{2} \mathrm{C}_{2} \mathrm{O}_{4} / 0.2 \mathrm{M} \mathrm{H}_{2} \mathrm{C}_{2} \mathrm{O}_{4}(\mathrm{pH} 3) \\
\text { in } 0.1 \mathrm{M} \text { ascorbic acid }\end{array}$ & 30 min at $95^{\circ} \mathrm{C}$ \\
\hline Step 8 & Residual & Digestion with $\mathrm{HF}-\mathrm{HClO}_{4}$ & \\
\hline
\end{tabular}

$30 \mathrm{~mL}$ of $0.1 \mathrm{M} \mathrm{Na}_{4} \mathrm{P}_{2} \mathrm{O}_{7}$ extract was brought to $1.0 \mathrm{pH}$ with the addition of $6 \mathrm{M} \mathrm{HCl}$ and the suspension was left overnight for humic acid. The suspension was centrifuged at $12000 \mathrm{~g}$ for $10 \mathrm{~min}$. Metal-fulvate complexes were determined in the supernatant. The residue was solubilised with $0.1 \mathrm{M} \mathrm{Na}_{4} \mathrm{P}_{2} \mathrm{O}_{7}$ and the metal-humate complexes were determined in the solution. 


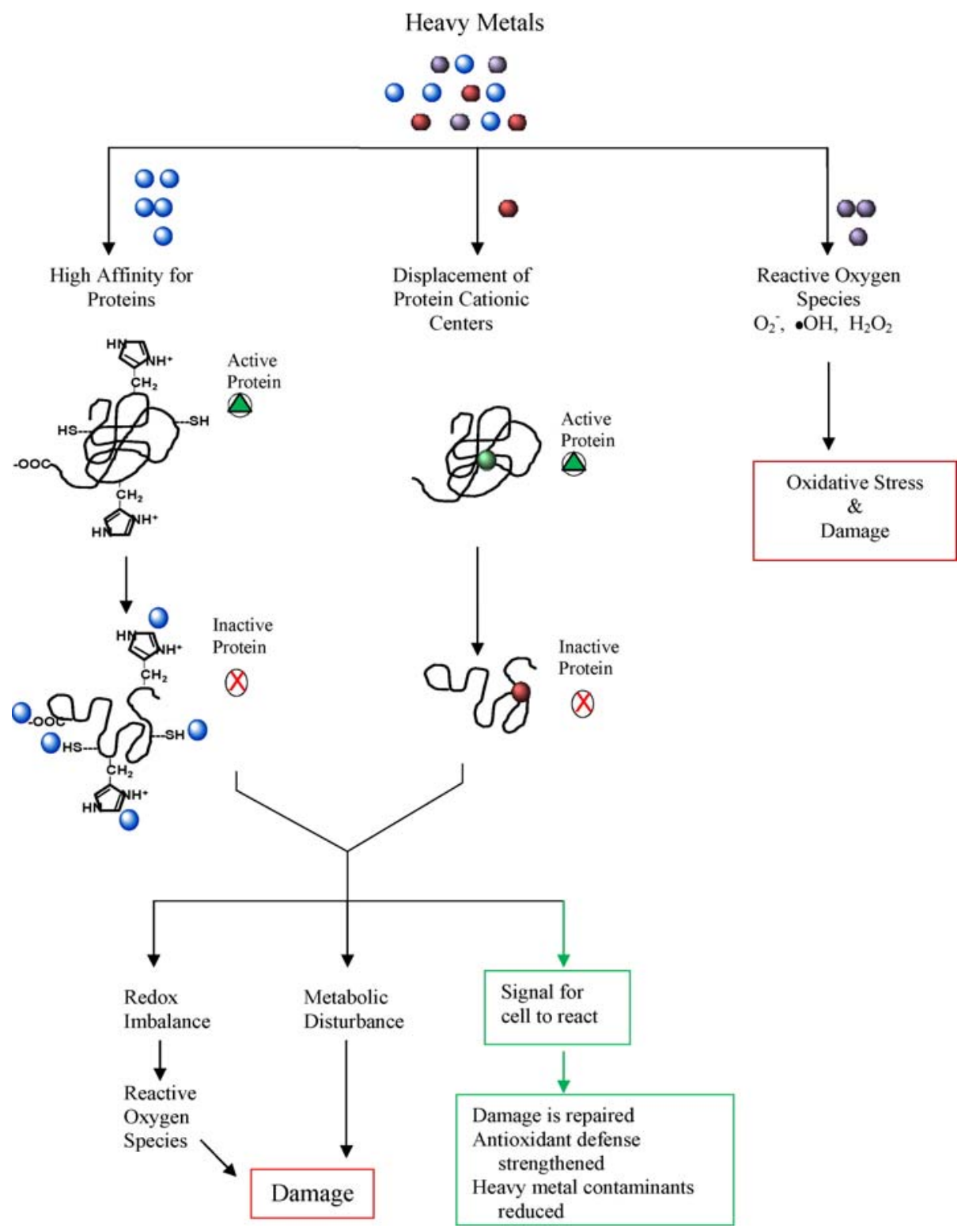

Figure 8. Heavy metal toxicity in plants. Purple spheres indicate redox active metals and red and blue are redox inactive metals. The green sphere is a metal centre that is displaced by a heavy metal (red). The affinity for heavy metals will alter the activity of the protein and create imbalances and disruption that will lead to macromolecular damage. However, the cell may adjust to the toxic metals and signal for reaction to prevent damage. 
to be significantly correlated with the metal-fulvate complex-bound $\mathrm{Cu}$ $(\mathrm{r}=0.944, \quad \mathrm{p} \leq 0001)$, exchangeable $\mathrm{Zn}$ $(\mathrm{r}=0.832, \mathrm{p}=0.002)$ and the metal-fulvate complex-bound $\mathrm{Cd}(\mathrm{r}=0.824, \mathrm{p}=0.002)$. It was observed that fulvic complex $\mathrm{Cu}$ could explain $89 \%$ of variation in phytoavailable $\mathrm{Cu}$, whereas the metalfulvate complex-bound element together with exchangeable element could explain $79 \%$ and $92 \%$ of variation in phytoavailable $\mathrm{Zn}$ and $\mathrm{Cd}$, respectively. Inclusion of solution element concentration in the regression analysis was not found to improve the predictability of phytoavailable element. The regression analysis indicated that phytoavailable $\mathrm{Cu}, \mathrm{Zn}$ and $\mathrm{Cd}$ in these soils are mainly from solid-phase fractions.

Recently, Krishnamurti et al. (2007) have studied copper mobility and phytoavailability on wheat durum (Triticum durum) grown in polluted and unpolluted Italian soils. The study was conducted to determine the solid phase distribution of copper in representative soils of Italy with wide differences in chemical and physicochemical properties. Selected sites varied in location as well as in current vegetation and land use. Samples with a high $\mathrm{Cu}$ load (132-253 mg $\mathrm{kg}^{-1}$ ) from a vineyard cultivation area were also included to study the contamination effect on $\mathrm{Cu}$ distribution among solid-phases. The solid phase fractionation of $\mathrm{Cu}$ in the soils was determined using a 8-step selective sequential extraction method (Table 3 ).

The results indicated that $\mathrm{Cu}$ was dominantly associated with organic binding sites $62.6-74.8 \%$. The relative importance of solid-phase fractions in assessing $\mathrm{Cu}$ phytoavailability by durum wheat in a greenhouse setting and the effectiveness of two soil tests, the DTPATEA and $\mathrm{NH}_{4} \mathrm{Cl}$ extraction method for predicting the phytoavailable $\mathrm{Cu}$ was studied. Most $\mathrm{Cu}$ was retained by roots with very limited translocation to the upper plant parts of wheat. A significant correlation $(\mathrm{r}=0.960, \mathrm{P}=0.0001)$ was found between plant $\mathrm{Cu}$ content and the $\mathrm{Cu}$ associated with the metal-fulvate complexes, indicating that phytoavailable $\mathrm{Cu}$ was mainly from metal-fulvate complexes. The contaminated soils had a significantly higher $\mathrm{Cu}$ proportion (77\%) associated with organic binding sites, in comparison with that of uncontaminated soil $(21.3 \%)$, resulting in higher proportion of phytoavailable $\mathrm{Cu}$.

Special sequences of extracting reagents are needed for the fractionation of metalloids such as arsenic and selenium as a consequence of their different oxidation states in soils. Several steps in fractionation analysis are performed under oxidizing or reducing conditions, whereby the original oxidation state can be altered. Although the extraction results might be questioned, they are definitely appropriate to assess the potential bioavailability of metalloids under environmental changing conditions (Gleyzes et al. 2002).

Wenzel et al. (2001) have developed an innovative and simple method for arsenic sequential extraction which provides the following five extraction steps with reagents gradually stronger (Table 4):

(1) $0.05 \mathrm{M}\left(\mathrm{NH}_{4}\right)_{2} \mathrm{SO}_{4}, 20^{\circ} \mathrm{C}-4 \mathrm{~h} ;$ (2) $0.05 \mathrm{M} \mathrm{NH}_{4} \mathrm{H}_{2} \mathrm{PO}_{4}, 20^{\circ} \mathrm{C}-16 \mathrm{~h}$; (3) $0.2 \mathrm{M}$ $\mathrm{NH}_{4}{ }^{+}$-oxalate buffer in the dark. $\mathrm{pH} 3.25$, $20^{\circ} \mathrm{C}-4 \mathrm{~h}$; (4) $0.2 \mathrm{M} \mathrm{NH}_{4}^{+}$-oxalate buffer+ ascorbic acid pH $3.25,96^{\circ} \mathrm{C}-0.5$ $\mathrm{h}$; (5) $\mathrm{HNO}_{3} / \mathrm{H}_{2} \mathrm{O}_{2}$ microwave digestion. 
Table 4. Sequential extraction procedure for arsenic (Wenzel et al. 2001) with permission.

\begin{tabular}{|c|c|c|c|c|}
\hline Fraction & Extractant & Extraction conditions & SSR & Washing step \\
\hline 1 & $\left(\mathrm{NH}_{4}\right)_{2} \mathrm{SO}_{4}(0.05 \mathrm{M})$ & $4 \mathrm{~h}$ shaking, $20^{\circ} \mathrm{C}$ & $1: 25$ & \\
\hline 2 & $\left(\mathrm{NH}_{4}\right) \mathrm{H}_{2} \mathrm{PO}_{4}(0.05 \mathrm{M})$ & $16 \mathrm{~h}$ shaking, $20^{\circ} \mathrm{C}$ & $1: 25$ & \\
\hline 3 & $\begin{array}{c}\mathrm{NH}_{4} \text {-oxalate buffer }(0.2 \mathrm{M}) ; \\
\text { pH } 3.25\end{array}$ & $\begin{array}{l}\text { 4h shaking in the dark, } \\
\qquad 20^{\circ} \mathrm{C}\end{array}$ & $1: 25$ & $\begin{array}{l}\mathrm{NH}_{4} \text {-oxalate }(0.2 \mathrm{M}) ; \mathrm{pH} \\
3.25 \mathrm{SSR} ; 1: 12.5 ; 10 \mathrm{~min} \\
\text { shaking in the dark }\end{array}$ \\
\hline 4 & $\begin{array}{l}\mathrm{NH}_{4} \text {-oxalate buffer }(0.2 \mathrm{M}) ;+ \\
\text { ascorbic acid }(0.1 \mathrm{M}) \mathrm{pH} 3.25\end{array}$ & $\begin{array}{l}30 \mathrm{~min} \text { in a water basin at } \\
96^{\circ} \mathrm{C} \pm 3^{\circ} \mathrm{C} \text { in the light }\end{array}$ & $1: 25$ & $\begin{array}{l}\mathrm{NH}_{4} \text {-oxalate }(0.2 \mathrm{M}) ; \mathrm{pH} \\
\text { 3.25 SSR; } 1: 12.5 ; 10 \mathrm{~min} \\
\text { shaking in the dark }\end{array}$ \\
\hline 5 & $\mathrm{HNO}_{3} / \mathrm{H}_{2} \mathrm{O}_{2}$ & Microwave digestion & $1: 50$ & \\
\hline
\end{tabular}

These fine As fractions appear to be primarily associated with (1) nonspecifically sorbed; (2) specifically sorbed; (3) amorphous and poorly-crystalline hydrous Fe and Al oxides; (4) well crystallized hydrous $\mathrm{Fe}$ and $\mathrm{Al}$ oxides $\mathrm{l}$; and (5) residual phases. These authors conducted a study using 20 Austrian soils differing in the level of As contamination

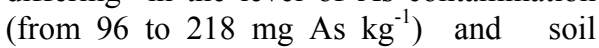
characteristics. The results showed that As was most prevalent in the two oxalate extractable fractions (30\% from step 3 and $27 \%$ from step 4 ), indicating that As is primarily associated with amorphous and crystalline $\mathrm{Fe}$ and $\mathrm{Al}$ oxides. The As fraction extracted by $\mathrm{NH}_{4} \mathrm{H}_{2} \mathrm{PO}_{4}$ represented about $10 \%$ of total $\mathrm{As}$ and may be useful in providing a relative measure of specifically-sorbed As in soils that may be potentially mobilized due to changes in $\mathrm{pH}$ or $\mathrm{P}$ addition. The amount of readily labile

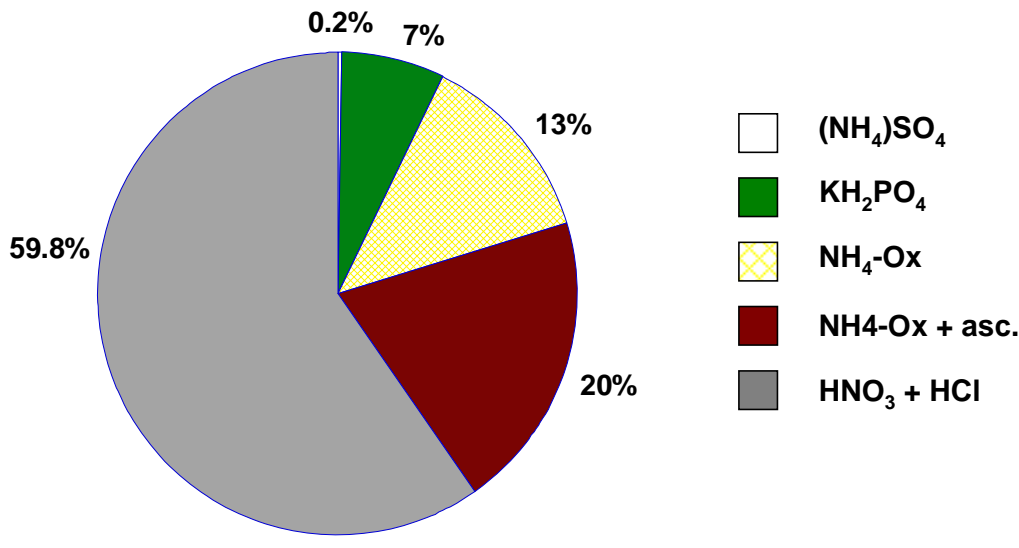

Figure 9. Arsenate fractionation from an Italian polluted soil (La Botte soil containing 190 mmol kg-1 of As), following Wenzel et al. (2001)' method (Redrawn from Branco, 2008). 
As extracted by $\left(\mathrm{NH}_{4}\right)_{2} \mathrm{SO}_{4}$ is generally small $(0.3 \%)$, but may represent the most important fraction related to environmental risks and has been shown to correlate well with As concentrations in field-collected soil solutions.

Recently, Branco (2008), using Wenzel et al. (2001) method, have studied the sequential As extraction from polluted Italian soils collected in Scarlino (Tuscany, Italy), which showed an arsenic content ranging from 100 to $190 \mathrm{mg} \mathrm{As} \mathrm{kg}{ }^{-1}$. Figure 9 shows As distribution in La Botte soil.

Arsenic was mostly recovered in the crystalline oxides $(59.8 \%)$ and shortrange $\mathrm{Fe}$ and $\mathrm{Al}$ oxides $(20 \%)$. The As fraction extracted with $\mathrm{NH}_{4} \mathrm{H}_{2} \mathrm{PO}_{4}$ was about $7 \%$, whereas the non-specifically sorbed (easily exchangeable) fraction that forms outer-sphere complexes onto the mineral surfaces was negligible $(<0.2 \%)$. The scarce residual As fraction (11-13\%) suggested a low presence of primary minerals rich in this metalloid.

\section{CONCLUSIONS}

Sorption-desorption processes of trace elements on or from soil components is affected by many factors, such as $\mathrm{pH}$, nature of the sorbents, redox reactions, and presence of organic and inorganic ligands. The behavior of foreign ligands on the sorption of trace elements in cationic form is quite different from that toward elements in anionic form. In fact, complexation reaction of trace elements in cationic form with organic and inorganic ligands have an important role to play in their sorption-desorption processes as well as in their toxicity and phytoavailability, whereas competition for available sites and/or reduction of the surface charge of the sorbents between foreign ligands and trace elements in anionic form affect primarily their mobility. Time of reaction and surface coverage have a great influence on the competitive sorption between trace elements and organic and inorganic ligands. Special sequences of extracting reagents are needed for the fractionation of heavy metals and metalloids in order to identify the species that are more available for plants and microorganisms.

\section{ACKNOWLEDGMENTS}

This research was supported by the Italian Research Program of National Interest (PRIN), year 2006. DiSSPAPA Number 255.

\section{REFERENCES}

Arai, Y., Sparks, D.L. 2002. Residence time effects on arsenate surface speciation at the aluminum oxide-water interface. Soil Sci.. 167, 303-314.

Baker, A.J.M. 1981. Accumulators and excluders strategies in the response of plants to heavy metals. J. Plant Nutr. 3, 643-654.

Beveridge, T.J. 1989a. Metal ions and bacteria. In: T.J. Beveridge, R.J. Doyle (eds). Metal Ions and Bacteria, R.J. Wiley, New York, pp: 1-29.

Beveridge, T.J. 1989b. Role of cellular design in bacterial metal accumulation and mineralization. Ann. Rev. Microbiol. 43, 147-171.

Borch, T., Kretzschmar, R., Kappler, A., Van Cappelen, P., Ginder-Vogel, M., Voegelin, A., Campbell, K. 2010. Biogeochemical redox processes and their impact on contaminant dynamics. Environ. Sci. \& Technol. 44, 15-23.

Borda, M.J., Sparks, D.L. 2008. Mobility of trace elements in soil environments. In: A. Violante., P.M. Huang, G.M. Gadd (eds). Biophysico-Chemical Processes of Metals and Metalloids in Soil Environments, John Wiley \& Sons, Hoboken, NJ, pp: 97-168.

Branco, A. 2008. Mobility and bioavailability of arsenic in italian polluted soils. $\mathrm{PhD}$ thesis, University of Naples (Italy) Federico II.122 p. 
Buffle, J. 1988. Complexation reactions in aquatic systems: an analytical approach. Ellis Horwood, Chichester, UK.

Capasso, R., Pigna, M., De Martino, A., Pucci, M., Sannino, F., Violante, A. 2004. Potential remediation of waters contaminated with $\mathrm{Cr}(\mathrm{III})$, $\mathrm{Cu}$ and $\mathrm{Zn}$ by sorption on the organic polymeric fraction of olive mill wastewater (polymerin) and its derivatives. Environ. Sci. \& Technol. 38, $5170-5176$.

Catalano, J.G., Park, C., Fenter, P., Zhang, Z. 2008. Simultaneous inner- and outer-sphere arsenate sorption on corundum and hematite. Geochim. Cosmochim. Acta 72, (8) 1986-2004.

Cornell, R.M., Schwertmann, U. 1996. The Iron Oxides. Structure, Properties, Reactions and Uses. VCH Publ., New York.

Fedotov, P.S., Mirò, M. 2008. Fractionation and mobility of trace elements in soils and sediments. In: A. Violante, P.M. Huang, G.M. Gadd. (eds). Biophysico-Chemical Processes of Heavy Metals and Metalloids in Soil Environments. WileyJupac Series, Vol 1 John Wiley \& Sons, Hoboken, NY, pp: 467-520.

Fendorf, S.E. 1995. Surface reactions of chromium in soils and waters. Geoderma 67, 5571

Fendorf, S.E., Eick, M.J., Grossl, P.R., Sparks, D.L. 1997. Arsenate and chromate retention mechanisms on goethite. I. Surface structure. Environ. Sci. Technol. 31, 315-320.

Filgueiras, A.V., Lavilla, I., Bendicho, C. 2002. Chemical sequential extraction for metal partitioning in environmental solid samples. J. Environ. Monit. 4, 823-857.

Gadd, J.M. 2008. Transformation and mobilization of metals, metalloids, and radionuclides by microorganisms. In: A. Violante, P.M. Huang, G.M. Gadd. (eds). Biophysico-Chemical Processes of Metals and Metalloids in Soil Environments. Wiley-Jupac Series, Vol 1 John Wiley \& Sons, Hoboken, NY pp: 53-96.

Gleysez, C., Tellier, S., Astruc, M. 2002. Fractionation studies of trace elements in contaminated soils and sediments: a review of sequential extraction procedures. Trends Anal. Chem. 21, 451-466.
Grossl, P.R., Eick, M.J., Sparks, D.L., Goldberg, S., Ainsworth, C.C. 1997. Arsenate and chromate retention on goethite. II. Kinetic evaluation using a p-jump relaxation technique. Environ. Sci. \& Technol. 31, 321326.

Helal, M.I.D. 2006. Sorption/desorption characteristics of heavy metal on amorphous $\mathrm{Al}$ and $\mathrm{Fe}$ hydroxides formed in the presence of oxalate, citrate and tannate ligands. J. Agronomy $5,440-450$.

Helavay, J., Prohaska, T., Weisz, M., Wenzel, W.W., Stingeder, G.J. 2004. Determination of trace elements bound to soils and sediment fractions. JUPAC Tech. Rep. Pure Appl. Chem. $76,415-442$.

Hsu, P.H. 1989. Aluminum hydroxides and oxyhydroxides. In: J.B. Dixon, S.B. Weed (eds). Minerals in Soil Environments. $2^{\text {nd }}$ edition, pp: 331-378.

Huang, J.V., Cunningham, S.D. 1996. Lead phytoextraction: species variation in lead uptake and translocation. New Phytol. 134, 73-84.

Huang, P.M., Gobran, G.R. 2005. Biogeochemistry of trace elements in the rhizosphere. Elsevier B.V. Amsterdam.

Huang, P.M., Germida, J.J. 2002. Chemical and biochemical processes in the rhizosphere: metal pollutants. In: P.M. Huang, J.-M. Bollag, N. Senesi (eds). Interactions Between Soil Particles and Microorganisms: Impact on the Terrestrial Ecosystem. John Wiley \& Sons, New York, pp: 381-438

Jackson, T.A., Leppard, G.G. 2002. Energy dispersive $\mathrm{x}$-ray microanalysis and its applications in biological research. In: A. Violante, P.M. Huang, J.M. Bollag, L. Gianfreda (eds). Soil Mineral-Organic-MatterMicroorganism Interactions and Ecosystem Health: Dynamics, Mobility and Trasformations of Pollutants and Nutrients, Developments in Soil Science, Vol. 28. Elsevier, New York, pp: 219260

Kampf, N., Scheinost, A.C., Schultze, D.G. 2000. Oxide Minerals. In: M.E. Sumner (ed). Handbook of Soil Science, ed., CRC Press, Boca Raton, FL, pp: F125-F168. 
Kinniburgh, D.G., Jackson, M.L. 1976 Adsorption of alkaline earth, transition and heavy metal cations by hydrous oxides gels of iron and aluminum. Soil Sci. Soc. Am. J. 40, 796-799.

Kinniburgh, D.G., Jackson, M.L. 1981. Cation adsorption by hydrous metal oxides and clays. In: M.A. Anderson, A.S. Rubin (eds). Adsorption of Inorganics at Solid-Liquid Interfaces. Ann Arbor Science, Ann Arbor, MI, pp: 91-160.

Krishnamurti, G.S.R., Naidu, R. 2008 Chemical speciation and bioavailability of trace metals.. In: A. Violante, P.M. Huang, G.M. Gadd (eds). Biophysico-Chemical Processes of Heavy Metals and Metalloids in Soil Environments. Wiley Interscience, New York, pp: 419-466.

Krishnamurti, G.S.R., Pigna, M., Arienzo, M. Violante, A. 2007. Solid-Phase Speciation and Phytoavailability of Copper in a Few Representative Soils of Italy. Chem. Spec.\& Bioav. 19, 57-67.

Krishnamurti, G.S.R., Naidu, R. 2002. Solidsolution speciation and phytoavailability of copper and zinc in soils. Environ. Sci. Technol. $36,2645-2651$

Krishnamurti, G.S.R., Naidu, R. 2000 Speciation and phytoavailability of cadmium in selected surface soils of south Australia. Aust. J. Soil Res. 38, 991-1004.

Krishnamurti, G.S.R., Cieslinski, G., Huang, P.M., Van Rees, K.C.J. 1997. Kinetics of cadmium release from soils as influenced by organic acids: implication in cadmium availability. J. Environ. Qual. 26, 271-277.

Krishnamurti, G.S.R., Huang, P.M., Van Rees, K.C.J. 1996. Studies on soil rhizosphere: speciation and availability of $\mathrm{Cd}$. Chem. Speciat. Bioavailab. 8, 23-28.

Krishnamurti, G.S.R., Huang, P.M., Van Rees, K. C. J., Kozak, L. M., Rostad, H. P.W 1995a. Speciation of particulate-bound cadmium of soils and its bioavailability. The Analyst. 120, 659-665.

Krishnamurti, G.S.R., Huang, P.M., Van Rees, K.C.J., Kozak, L.M., Rostad, H.P.V. 1995b. A new soil test method for the determination of plant available cadmium in soils. Commun. Soil Sci. Plant Anal. 26, 857-2867.
Lopez, A., Lazaro, N., Priego, J.M., Marques, A.M. 2000. Effect of $\mathrm{pH}$ on the adsorption of nickel and other heavy metals by Pseudomonas fluorescens 4F39. J. Ind Microbiol. Biotechnol. 24, 146-151.

Manning, B.A., Goldberg, S. 1996. Modelling competitive adsorption of arsenate with phosphate and molybdate on oxide minerals. Soil Sci. Soc. Am. J. 60, 121-131.

Martin, M., Celi, L., Barberis, E., Violante, A. Kozac, L.M., Huang, P.M. 2009. Effect of humic acid coating on arsenic adsorption on ferrihydrite-kaolinite mixed systems. Canadian J. of Soil Sci. 89, 421-434.

McBride, M.B. 1982. $\mathrm{Cu}^{2+}$-adsorption characteristics of aluminum hydroxide and oxyhydroxides. Clays Clay Miner. 30, 21-28.

McBride, M.B. 1994. Environmental Chemistry of Soils, Oxford University Press, New York

McKenzie, R.M. 1980. The adsorption of lead and other heavy metals on oxides of manganese and iron. Aust. J. Soil Res. 21, 505-513.

McGrath, S.P., Zhao, F.J., Lombi, E. 2002. Phytoremediation of metals, metalloids, and radionuclides. Adv. Agric. 75, 1-56.

O'Reilly, S.E., Strawn, D.G., Sparks, D.L. 2001. Residence time effects on arsenate adsorption/desorption mechanisms on goethite. Soil Sci. Soc. Am. J. 65, 67-77.

Perelomov, L., Cozzolino, V., Pigna, M., Violante, A. 2010. Adsorption of $\mathrm{Cu}$ and $\mathrm{Pb}$ on goethite in the presence of low molecular mass aliphatic acids. Geomicrobiol. J. in press.

Pigna, M., De Santis, R., Cozzolino, V. Violante, A. 2010. Influence of organic and inorganic ligands on the adsorption of arsenate and arsenite onto ferrihydrite. Geoderma in Press.

Senesi, N. 1992. Metal-humic substance complexes in the environment. Molecular and mechanistic aspects by multiple spectroscopic approach.. In: D.C. Adriano (ed). Biogeochemistry of Trace Elements. Lewis, Boca Raton, FL, pp: 429. 451.

Senesi, N., Loffredo, E. 1998. The chemistry of soil organic matter. In: D.L. Sparks (ed). Soil Physical Chemistry. $2^{\text {nd }}$ edition, CRC Press, Boca Raton, FL, pp: 239-370. 
Sparks, D.L. 2003. Environmental Soil Chemistry. $2^{\text {nd }}$ edition. Academic Press, San Diego.

Sparks, D.L. 1990. Kinetics of Soil Chemical Processes. Academic Press, San Diego, CA.

Sposito, G. 1984. The surface chemistry of soils, Oxford Univ. Press, 234 p.

Templeton, D.M., Ariese, F., Cornelis, R., Danielson, L.-G., Munau, H., van Leeuwen, H.P., Lobinski, R. 2000. Guidelines for terms related to chemical speciation and fractionation of elements. Definition, structural aspects and methodological approaches (JUPAC Recommendation 2000). Pure Appl. Chem. 72, 1453-1470.

Ure, A.M., Davison, C.M. 2002. Introduction. In: A.M. Ure, C.M. Davison (eds). Chemical Speciation in the Environment, $2^{\text {nd }}$ edition, ed, C.M., Blackwell Science, Oxford, pp: 1-5.

Vacca, A., Adamo, P., Pigna, M., Violante, P. 2002. Properties and classification of selected soils from the Roccamonfina volcano, CentralSouthern Italy. Soil Sci. Soc. Am. J. 67, 198-207.

Violante, A., Krishnamurti, G.S.R., Pigna, M 2008. Mobility of Trace Elements in Soil Environments. In: A. Violante, P.M. Huang, G.M. Gadd (eds). Biophysico-Chemical Processes of Metals and Metalloids in Soil Environments. John Wiley \& Sons, Hoboken, NJ, pp: 169-213.
Violante, A., Ricciardella, M., Pigna, M., Capasso, R. 2005. Effects of organic ligands on the sorption of trace elements onto metal oxides and organo-mineral complexes. In: P.M. Huang, G.R. Gobran (eds). Biogeochemistry of Trace Elements in the Rhizosphere, Elsevier B.V, pp: 157-182.

Violante, A., Ricciardella, M., Pigna, M. 2003. Adsorption of Heavy Metals on Mixed Fe-Al Oxides in the Absence or Presence of Organic Ligands. Water Air and Soil Poll. 145, 289-306.

Violante, A., Pigna, M. 2002. Competitive sorption of arsenate and phosphate on different clay minerals and soils. Soil Sci. Soc. Am. J. 66, 1788-1796.

Wenzel, W.W., Kirchbaumer, N., Prohaska, T., Stingeder, T., Lombi, E., Adriano, D.C. 2001. Arsenic fractionation in soils using an improved sequential extraction procedure. Anal. Chim. Acta 436, 309-323.

Zachara, J.M., Ainsworth, C.C., Cowan, C.E., Resch, C.T. 1989. Adsorption of chromate by subsurface soil horizons. Soil Sci. Soc. Am. J. $53,418-428$ 